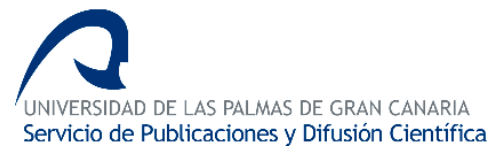

PHLEledertet

Philologica Canariensia 23 (2017), pp. 7-17 eISSN: 2386-8635

DOI: 10.20420/PhilCan.2017.145

Received: 4 September 2016; revised version accepted: 21 November 2016

Published online: 26 June 2017

\title{
CULTURE AND INSTRUCTION \\ IN THE SPANISH HERITAGE LANGUAGE CLASSROOM
}

\author{
Clara BuRgo \\ Loyola University Chicago
}

\begin{abstract}
Since cultural competence is inherent to language acquisition, it should take a central role in heritage language courses so that heritage language learners (HLLs) can make connections with their own culture and be aware of the diversity of the Spanish-speaking world. This article presents an overview of the instruction and assessment of culture to promote critical thinking and reflection in order to reduce stereotypes and to validate the cultural heritage of HLLs. The current role of study abroad and service-learning to teach culture in the Spanish heritage language classroom is also discussed.
\end{abstract}

KEYWORDS: assessment, cultural competence, intracultural knowledge, intercultural knowledge

Cultura e instrucción en la clase de español como lengua de herencia

RESUMEN: Como la competencia cultural es inherente a la adquisición de la lengua, debería jugar un papel central en los cursos de lengua de herencia, de modo que los aprendientes puedan establecer conexiones con su propia cultura y ser conscientes de la diversidad del mundo hispanohablante. Este artículo ofrece una visión panorámica de la instrucción y evaluación de la cultura para promover el pensamiento crítico y la reflexión, a fin de reducir los estereotipos y validar la herencia cultural de los aprendientes de lengua de herencia. Asimismo, se analiza el papel actual de los estudios en el extranjero y del aprendizaje-servicio para enseñar cultura en la clase de español como lengua de herencia.

PALABRAS CLAVE: evaluación, competencia cultural, conocimiento intracultural, conocimiento intercultural

\section{INTRODUCTION}

The American Council on the Teaching of Foreign Languages (ACTFL) defines the teaching of culture as "to gain knowledge and understanding of other cultures" (Beaudrie, Ducar, and Potowski, 2014, 178). This definition is based on products, practices, and perspectives. The concept of products refers to "Culture", what people usually think about what culture is (including works of art or literature, and customs). Practices, on the other hand, refer to social patterns or manifestations of a cultural group, and perspectives refer to a particular view of the world. These last two concepts pertain to the notion of "culture". Moran (2001) adds two more 
dimensions: persons and communities (individual members of a culture, and groups of individuals in the same culture).

One of the most debated issues in the pedagogy for heritage language learners (HLLs) is the role of cultural competence in the curriculum, allowing HLLs to develop a cultural awareness to connect with their communities (Samaniego and Pino, 2000; Valdés, 2000; Webb and Miller, 2000). What is undeniable is that cultural competence should take a central role in HLLs' courses, since it is inherent to language acquisition, and HLLs need to make connections between the culture they are taught and their own culture to become familiar with the diversity of the Spanish-speaking world and reduce stereotypes. According to Duarte (2014), research suggests that instructors should prioritize culture over linguistic learning. Regarding teaching approaches, the emphasis should be on examining culture's practices and perspectives despite the limitation of a perceived lack of time for culture in the curriculum and its reduction to stereotypes (Beaudrie et al., 2014). Thus, how can culture be taught to Spanish HLLs in order to help them reconnect with their roots and heritage? Can we use the same teaching approaches as we would for L2 learners, since HLLs are bicultural and have cultural practices from the US and their heritage culture? This article intends to provide a state of affairs in the field of HLLs' culture instruction.

\section{CULTURE AND INSTRUCTION}

\subsection{Approaches to the teaching of culture}

Whereas L2 cultural knowledge pertains to the academic concept of "Culture", HLLs' knowledge pertains to a set of community practices ("culture"). Therefore, HLLs can assume expert roles in the classroom and play a departure role for cultural discussions, although teachers should be sensitive towards a potential negative reaction by them (Beaudrie et al., 2014). In a questionnaire administered to Spanish HLLs in a southwestern US university, students reported a desire to spend more class time dedicated to cultural activities to increase the development of their identities and their understanding of their cultural heritage (Beaudrie, Ducar, and Relaño-Pastor, 2009). Beaudrie et al. (2009) even suggest offering courses for HLLs that are just focused on culture.

In fact, HLLs have different cultural needs than L2 learners. Carreira (2004) emphasizes the importance of increasing the linguistic self-esteem of HLLs, reinforcing their identities, and reconnecting with their heritage culture. Culture is then explored by HLLs as insiders of the local communities. Potowski and Carreira (2004) recommend offering HLLs the tools to explore cultural practices for academic achievement and progress.

Specifically for Spanish HLLs, Aparicio (1997) proposes three levels of cultural knowledge: self-cultural knowledge, intracultural knowledge, and intercultural knowledge about other Latino groups in the US. This third level is especially important since their US cultural features could have an impact on their community practices and perspectives. In order to achieve cultural awareness of diversity, instructors should offer a diverse curriculum content and culturally-sensitive instruction (Beaudrie, 2012). Morris and Mims (2012) propose some steps to create culturally-sensitive classrooms: foster a multicultural climate where students can 
bring items from their background to enhance their self-esteem, involve students so that they learn about their heritage, and use multi-ethnic books.

Regarding teaching methodologies, Villa (1996) proposes showing respect for the different cultures and dialects as an acknowledgement of the diversity of the Latino community in the US. Faltis (1990) suggests creating courses with a cultural basis appealing to HLLs, and Aparicio (1983) incorporates cultural projects as a class assignment. Evidently, it is crucial that instructors be familiar with the HLLs' home culture and make their knowledge visible in the classroom (Hunter, 2011). Beyond this, their identity has to be incorporated into the culture of the classroom to avoid the inhibition of their learning process (Feuerverger, 1997; McGinnis and Palos, 2011; Menard-Warwick, 2009).

Zimmerman (2011) proposes using a culturally-responsive pedagogy for Spanish HLLs. This model is based on the cultural knowledge of diverse students. According to Guy (1999), in the case of HLLs the focus should be on considering their cultural and linguistic knowledge as strengths instead of weaknesses. Culturally-responsive teaching is based on two principles: the ethics of care (Nodding, 1999) and the ethics of fair teaching. Each student has the right to tell his/her own story, and they need a curriculum that reflects their realities. An effective curriculum would contain: an interdisciplinary approach connected to students' lives, opportunities to develop higher-order cognitive skills, and different learning styles (Ekiaka Nzai, Gómez, Reyna, and Jen, 2012). Banks (2004) and McIntosh (2000) claim that mainstream curricula are Euro- and male-centric, ignoring the voices of the minorities. Therefore, as instructors we should start modifying the curriculum design and the educational materials. Instructional conversation is a culturally-responsive practice highly recommended for culturally-diverse students such as Spanish HLLs. It consists of a reflexive discussion that promotes critical thinking and student engagement (Cazden, 1988). Ekiaka Nzai et al. (2012) propose additional strategies such as contrast instruction by which students study other cultures that are not their own, so that they can make a comparison, and jurisprudential instruction to discuss social issues. According to Cullen and Sato (2000), there are several sources to teach culture: videos, blogs, internet, songs, literature, newspapers, or Virtual Realia (Smith, 1997). This latter refers to digitized items from the target culture that are brought to the classroom to stimulate oral or written production. In sum, as they increase their proficiency in Spanish, HLLs are provided with the opportunity to strengthen their ties with their own communities (Leeman and Martínez, 2007).

According to Ladson-Billings (1995), culturally-relevant instruction empowers HLLs by allowing them to develop a critical awareness to challenge the status quo. For Ladson-Billings, following this pedagogical approach students have to achieve academic success, cultural competence, and critical awareness. The ultimate goal would be to directly address students' needs and motivate students that have been traditionally marginalized into an engagement with literacy (Godina, 2003). An example of a culturally-responsive teaching approach is story telling as a learning tool for teachers and students and as a holistic way of understanding the community practice of HLLs (Gay, 2003). From a multicultural perspective, instructors need to provide learners with authentic texts and reflect the diverse realities and cultural perspectives of HLLs (Gray, 2003). 
Cross-cultural awareness allows HLLs to make connections with the diversity of the Latino cultures in the US while appreciating their own (Beaudrie et al., 2009). This awareness would imply that culture is treated as practice (González, Moll, and Amanti, 2005). In a study conducted by Beaudrie et al. (2009) on students' opinions regarding cultural identity in their courses for HLLs, they found that students reported gains in pride and self-identification (identity awareness). Concerning the treatment of culture by textbooks, HLLs reported that there was less emphasis on culture at the higher levels. This issue is relevant for both instructors and students, since in most cases the classroom is the only opportunity for them to reconnect with their cultural heritage. Thus, they suggested offering extra-curricular activities for them such as establishing contact with surrounding Spanish-speaking communities (when possible) as a service-learning opportunity (beneficial for both the students and the community), so that HLLs become active members of their own community. Furthermore, Beaudrie et al. mention the importance of the funds of knowledge approach to empower the students; we have to acknowledge the cultural and linguistic knowledge that they bring to the classroom.

In heritage language education we should also find the goal of acquiring cultural literacy. Cultural competence is not necessarily linked to linguistic competence, but there is not communicative competence without cultural competence. In fact, cultural competence is required for language acquisition (Pérez Pérez, 2012; Porcher, 1986). Since improving literacy is one of the main objectives for Spanish for HLLs' courses, Stern (2004) proposes designing a course to validate the students' cultural heritage. In terms of activities, Zimmerman (2009) suggests using Google Maps to track the cultural roots and linguistic varieties of the HLLs. Local sites should also be offered as alternatives to the classroom, so that culture is embedded in the curriculum (Zimmerman, 2011). Ethnographic research has also been recommended for advanced learners (Coronado, 1999). Thus, it could also be applied to HLLs as a direct source of cultural input to connect with their families and their roots.

Carreira and Kagan (2011) propose community-based instruction as a link between the classroom and the community. Students need to be able to function in the community at the same time that they develop and amplify their competence in Spanish. As instructors, we need to know the community to integrate it into the curriculum and connect the learner with the community to understand this interaction. Leeman (2015) argues that despite the interest in the role of identity in the heritage educational discourse, it has not been until recently that there has been empirical research on how identity is constructed in these contexts.

\subsection{Classroom assignments}

Concerning classroom assignments for HLLs that enhance their cultural knowledge, students can conduct ethno-linguistic (Beaudrie et al., 2014) and oral history interviews to do research within their own communities, or video-based projects for intracultural comparison in the US (Ross and Charitos, 2012). Another interactive way of incorporating HLLs' culture in the classroom is via pop culture, which is usually familiar to them. In order to do so, the curriculum should be project-oriented and consider the interests of the HLLs themselves, so that there is an increased interaction with their own respective heritage culture (Choi and Yi, 2002). 
From an intercultural perspective, open discussions and critical debates are promoted so that stereotypes and prejudices can be questioned. In order to achieve cultural awareness, learners need to distance themselves from their own culture so that they can reflect upon it (Andersson, Persson, and Thavenius, 1999).

\subsection{Assessment of the cultural competence of HLLs}

Another issue that presents a challenge when teaching culture is that of assessment for there is not consensus in its instructional goals as a starting point, and there is not necessarily a requirement to assess it in the curriculum. Gago (2008) suggests having social debates with communicative exchanges to get closer to the cultural reality of the Other. Another proposal to assess cultural competence could be portfolios or reflection papers (Schulz, 2007), video diaries, and blogged discussions (Beaudrie et al. 2014).

On the other hand, Kagan and Dillon (2001) make a comparison between non-HLLs and HLLs regarding pedagogical cultural needs in the classroom. Whereas non-HLLs would benefit from a micro-approach, HLLs would need a macro-approach with an ample variety of input. Carreira (2004) argues that the curriculum should focus on the culture of US Latinos. This way, students can contribute with their own experiences. She specifically mentions that classroom discussion should focus on how the Spanish language and culture are lost across generations of immigrants, and what the consequences of this loss in the community are.

One aspect to consider is how students assess the importance of culture in the curriculum. In a study by Beaudrie et al. (2009), students emphasized the importance of the cultural role in their linguistic growth. In this study, Mexican-American students took the Spanish heritage course in order to be able to connect with their heritage culture. Students' answers showed that it was necessary to include "Culture" and "culture" for cultural awareness and reflection. They felt they had gained a better understanding of their identity. Moreover, they appreciated being involved in cultural activities to build connections with their heritage and community (Alarcón, 1997; Webb and Miller, 2000) and maintain their language (Oh and $\mathrm{Au}$, 2005). Knutson (2006) proposed that the first thing all learners need to know about learning culture is how to behave properly culturally-speaking.

Regarding cultural activities for students in and outside the classroom, Beaudrie and Ducar (2005) suggest that HLLs use interviews to acquire a deeper knowledge of their community members in order to become more involved in the community itself. Schwarzer and Petrón (2005) emphasize the importance of including social issues in the curriculum, such as bilingual education, as well as using assorted materials and exploring different ways of assessment. That is, dealing with identity issues is necessary in order to address students' needs. Additionally, Beaudrie et al. (2009) propose conducting interviews, attending social events, or engaging in cultural projects with the objective of making the students active participants in their communities. As these researchers argue, culturally-relevant instruction is recommended to give students the opportunity to show their culture in class and to keep them engaged and motivated.

Fairclough and Belpoliti (2013) also suggest cultural projects, but based on scaffolding and research activities to develop the linguistic competence of HLLs. For these projects, the 
students collect data from an immediate context extended to the community in order to become familiar with their heritage culture. At the end of the semester, they present their results via oral presentations and essays. The expectation is that students will use their local varieties to collect data and the standard register for the oral presentations and essays. Therefore, students have to show domain of both registers.

In a community-based curriculum, however, the activities, such as interviews, oral histories, and research into the historical past, are oriented towards the community. In order to implement this, instructors have to be trained to guide students to conduct these projects (Kagan and Dillon, 2009). Another example of this kind of projects is the ethnographic interview. Rodríguez Pino (1997) explains how these interviews are important to get insight into the perspective of the community through an insider. In the same vein, Peterson and Coltrane (2003) add that they offer HLLs an opportunity to express themselves regarding their lives and that of the community, thus empowering them. From a content-based approach, Roca (2007) suggests some cultural activities: autobiographies, oral interviews, discussion about the meaning of being bilingual, being involved in community-based events, preparing for an imaginary trip to a Hispanic country, and presenting on cultural topics from the textbook.

\section{THE ROLE OF SERVICE-LEARNING AND STUDY ABROAD IN THE ACQUISITION OF CULTURAL COMPETENCE FOR HLLS}

Study abroad programs are not usually designed specifically for HLLs. Nevertheless, there is an increase of HLLs studying abroad. These students face different challenges than their L2 counterparts, such as identity issues as a consequence of living between two worlds, the US and the heritage country (Rubin, 2004). In this vein, Carrasco and Riegelhaupt (2003) found that Spanish HLLs, specifically Mexican-Americans, underwent an identity crisis due to a cultural clash when living with Mexican host families while studying abroad. Thus, more sociocultural knowledge is needed for both HLLs and the host families.

On the other hand, service-learning opportunities have a different spin for HLLs. They should be provided with expert roles to promote student engagement and resist subordinating ideologies (Martínez and Schwartz, 2012). Even within the same institution, students can perform mentor roles with other student peers. Outside of the university, they can also use their local varieties as a valuable mean to communicate within medical contexts. Furthermore, service-learning allows HLLs the opportunity to move towards the maintenance of their linguistic and cultural background and knowledge (Leeman, Rabin, and RománMendoza, 2011b).

Research on service-learning programs for HLLs is scarce. A few recent studies focus on Spanish as a heritage language. Some of them are based on critical pedagogy approaches to inquire about identity issues. Critical pedagogy consists of sharing the instructor's own cultural background with the students to build an inclusive environment in the classroom (Ducar, 2008; Samaniego and Pino, 2000). For example, Leeman (2011a, 2011b) investigated a critical service-learning internship program in which college HLLs supervised a heritage language program in an elementary school. The rationale behind this internship was to legitimate their expertise as HLLs as part of building their identities. This was assessed via interviews and 
reflections, and it was found that the HLLs indeed gained confidence in their Spanish as members of the community. Nevertheless, it seems this confidence was leaning more towards feeling like native speakers of the heritage language rather than validating their dialects.

Petrov (2013) conducted a pilot study on her intermediate heritage Spanish course. She highlighted the importance of attitudinal objectives such as exploring local Latino communities in order to generate a positive construction of Latino identities. Tijunelis, Satterfield, and Benkí (2013) conducted a case study on a service-learning program in a Saturday school in Michigan. The study showed that HLLs and their parents are part of a community that values bilingualism and their literacy in Spanish. They mentioned some advantages of service-learning programs over study-abroad programs: the US context allows students to interact with Spanish native speakers who live in the US. Martínez and Schwartz (2012) also argue that community engagement is crucial for HLLs' learning. This context motivates students more than a classroom setting, legitimizes the voice of the students and the community, and revitalizes the community itself. In the same vein, Lowther Pereira (2015) conducted a study on an advanced course for HLLs with a service-learning component to enrich students' cultural and linguistic knowledge via involvement with a local Latino community. The ultimate cultural goal, among other goals, was creating positive cultural identities. Results showed that students felt more connected to their local communities thanks to this experience and became more aware of the social issues affecting them. Lowther Pereira interpreted these results as evidence of service-learning being a successful critical pedagogy for HLLs. Pak (2016) examined service-learning as a proposal for a culturally-relevant pedagogy to enhance HLLs' sense of belonging. Students used reflective writings to express their thoughts on the experience and they found connections with their sociocultural identities, increased confidence in themselves, and an interest in community engagement. In this servicelearning program, there was additionally a tutoring project at the end of the semester. Among the benefits of service-learning for HLLs, Parra (2013) mentions linguistic and cultural gains. Regarding cultural gains, she emphasizes an awareness of dialectal variation and of the diversity of the Latino community.

\section{CONCLUSIONS}

Despite the importance of the instruction of culture as a skill in the Spanish heritage classroom, there is scarce classroom research on effective practices for teaching and assessing culture. Culturally-responsive and culturally-relevant instruction have been recommended for students to acquire communicative competence and reconnect with their heritage cultures from an insider's perspective (Godina, 2003; Guy, 1999; Zimmermann, 2011).

Concerning cultural activities and their assessment, a macro-approach should be chosen with assorted input options (Kagan and Dillon, 2001). Students assess the cultural component of their Spanish heritage courses in a positive way, since it allows them to reconnect with their heritage culture or to deal with identity issues via ethnographic interviews and oral history projects, among others.

Even though there are not many study-abroad programs specifically designed for HLLs, there is an increasing number of HLLs who are choosing this option to study Spanish in an 
immersion context abroad. Therefore, future research should study these programs and the experience of HLLs there. Regarding service-learning programs, even though more empirical research can be found in the literature, there is a need for more service-learning courses or programs for HLLs, since most of these follow a critical pedagogy approach that is directly linked with identity issues, one of the main goals in the teaching of culture.

\section{REFERENCES}

ALARCÓN, F. X. 1997. “El español para hispanohablantes: la cultura, ¿cómo se come?, o quítale las hojas al tamal”, en Colombi, M. C. and Alarcón, F. X. (eds.), La enseñanza del español a hispanohablantes: Praxis y teoría. Boston: Houghton Mifflin, 233-257.

ANDERSSON, L., PERSSON, M., and THAVENIUS, J. 1999. Skolan och de kulturella förändringarna. Lund: Studentlitteratur.

APARICIO, F. 1983. "Teaching Spanish to the Native Speaker at the College Level", Hispania, 66(2), 232-239.

APARICIO, F. 1997. "La enseñanza del español para hispanohablantes y la pedagogía multicultural”, en Colombi, M. C. and Alarcón, F. X. (eds.), La enseñanza del español a hispanohablantes: Praxis y teoría. Boston: Houghton Mifflin, 222-232.

BANKS, J. 2004. “Approaches to Multicultural Curriculum Reform”, in Banks, J. and Banks, C. (eds.), Multicultural Education: Issues and Perspectives. San Francisco, CA: Jossey-Bass, 242-264.

BEAUDRIE, S. 2012. "Common Core State Standards and Heritage Language Education: How Do They Match?”, The NCLRC Language Resource, 15(15).

BEAUDRIE, S. and DUCAR, C. 2005. "Beginning Level University Heritage Programs: Creating a Space for All Heritage Language Learners", Heritage Language Journal, 3(1), 1-26.

BEAUDRIE, S., DUCAR, C., and POTOWSKI, K. 2014. Heritage Language Teaching: Research and Practice. Columbus, $\mathrm{OH}$ : McGraw-Hill Education.

BEAUDRIE, S., DUCAR, C., and RELAÑO-PASTOR, A. M. 2009. "Curricular Perspectives in the Heritage Language Context: Assessing Culture and Identity", Language, Culture and Curriculum, 22(2), 157-174.

CARRASCO, R. L. and RIEGELHAUPT, F. 2003. "META: A Model for the Continued Acquisition of Spanish by Spanish/English Bilinguals in the United States”, in Roca, A. and Colombi, M. C. (eds.), Mi lengua: Spanish as a Heritage Language in the United States. Washington, DC: Georgetown University Press, 170-197.

CARREIRA, M. 2004. "Seeking Explanatory Adequacy: A Dual Approach to Understanding the Term 'Heritage Language Learner”, Heritage Language Journal, 2(1), 1-25.

CARREIRA, M., and KAGAN, O. (2011). "The Results of the National Heritage Language Survey: Implications for Teaching, Curriculum Design, and Professional Development”, Foreign Language Annals, 44(1), 40-64.

CAZDEN, C. 1988. Classroom Discourse: The Language of Teaching and Learning. Portsmouth, NH: Heinemann.

CHOI, J. and YI, Y. 2012. "The Use and Role of Pop Culture in Heritage Language Learning: A Study of Advanced Learners of Korean”, Foreign Language Annals, 45(1), 110-129.

CORONADO, M. L. 1999. "La integración de lengua y cultura en los niveles avanzado y superior: reflexiones y actividades”, Carabela, 45, 93-106. 
CULLEN, B. and SATO, K. 2000. "Practical Techniques for Teaching Culture in the EFL Classroom", The Internet TESL Journal, 6 (12). Retrieved from http://iteslj.org/Techniques /Cullen-Culture.html.

DUARTE, E. A. 2014. "Spanish as a Heritage Language in the United States: An Overview", Comunicación, cultura y política, 5(2), 32-52.

DUCAR, C. 2008. "Student Voices: The Missing Link in the Spanish Heritage Language Debate", Foreign Language Annals, 41(3), 308-320.

EKIAKA NZAI, V., GÓMEZ, P., REYNA, C., and JEN, K. 2012. "Non-Native English Speaking Elementary ELL Teachers' Culturally Responsive Leadership Profile in an ESL Context", Colombian Applied Linguistics Journal, 14(2), 88-108.

FAIRCLOUGH, M. and BELPOLITI, F. 2013. "Houston's Hispanic Community: Understanding Culture through Research in the SHL Classroom", 24th Conference on Spanish in the United States and 9th Conference on Spanish in Contact with Other Languages. McAllen, TX: University of Texas - Pan American.

FALTIS, C. 1990. "Spanish for Native Speakers: Freirian and Vygotskian Perspectives", Foreign Language Annals, 2(2), 117-26.

FEUERVERGER, G. 1997. "On the Edges of the Map: A Study of Heritage Language Teachers in Toronto", Teaching and Teacher Education, 13(1), 30-53.

GAGO, E. 2008. “Permeabilidad y asimilación de contenidos socioculturales: evaluación”, in Pastor Cesteros, S. and Roca Marín, S. (eds.), La evaluación en el aprendizaje y la enseñanza del español LE/L2: XVIII Congreso Internacional de la Asociación para la Enseñanza del Español como Lengua Extranjera (ASELE). Alicante: Secretariado de Publicaciones de la Universidad de Alicante, 263-269.

GAY, G. 2003. "Introduction: Planting Seeds to Harvest Fruits", in Gay, G. (ed.), Becoming Multicultural Educators: Personal Journey Toward Professional Agency. San Francisco, CA: Jossey-Bass, 1-16.

GODINA, H. 2003. "Mesocentrism and Students of Mexican Background: A Community Intervention for Culturally Relevant Instruction”, Journal of Latinos and Education, 2(3), 141-157.

GONZÁLEZ, N., MOLL, L. C., and AMANTI, C. 2005. Funds of Knowledge: Theorizing Practices in Households, Communities, and Classrooms. Mahwah, NJ: Lawrence Erlbaum.

GRAY, A. 2003. "Conversations with Transformative Encounters", in Gay, G. (ed.), Becoming Multicultural Educators: Personal Journey Toward Professional Agency. San Francisco, CA: Jossey-Bass, 67-90.

GUY, T. 1999. "Culture as Context for Adult Education: The Need for Culturally Relevant Adult Education”, in Guy, T. (ed.), Providing Culturally Relevant Adult Education: A Challenge for the Twenty-First Century. San Francisco, CA: Jossey-Bass, 5-18.

HUNTER, T. 2011. "Responding to Cultural and Linguistic Diversity in New Zealand: A Ministry of Education Project”, Language, Education and Diversity Conference. Auckland, New Zealand.

KAGAN, O. and DILLON, K. 2001. "A New Perspective on Teaching Russian: Focus on the Heritage Learner”, Slavic and East European Journal, 45, 507-518.

KAGAN, O. and DILLON, K. 2009. "The Professional Development of Teachers of Heritage Learners: A Matrix", in Anderson, M. and Lazaraton, A. (eds.), Building Contexts, Making Connections: Selected Papers from the Fifth International Conference on Language Teacher Education. Minneapolis, MN: Center for Advanced Research on Language Acquisition, 155-175.

KNUTSON. E. 2006. "Cross-Cultural Awareness for Second/Foreign Language Learners", The 
Canadian Modern Language Review, 62(4), 591-610.

LADSON-BILLINGS, G. 1995. "But That's Just Good Teaching! The Case for Culturally Relevant Pedagogy”, Theory Into Practice, 34(3), 159-165.

LEEMAN, J. 2015. "Heritage Language Education and Identity in the United States", Annual Review of Applied Linguistics, 35, 100-119.

LEEMAN, J. and MARTINEZ, G. 2007. "From Identity to Commodity: Ideologies of Spanish in Heritage Language Textbooks", Critical Inquiry in Language Studies, 4, 35-65.

LEEMAN, J., RABIN, L., and ROMÁN-MENDOZA, E. 2011a. "Critical Pedagogy Beyond the Classroom Walls: Community Service-learning and Spanish Heritage Language Education”, Heritage Language Journal, 8(3), 1-22.

LEEMAN, J., RABIN, L., and ROMÁN-MENDOZA, E. 2011b. "Identity and Activism in Heritage Language Education”, Modern Language Journal, 95(4), 481-495.

LOWTHER PEREIRA, K. 2015. "Developing Critical Language Awareness via Service-learning for Spanish Heritage Speakers”, Heritage Language Journal, 12(2), 159-185.

MARTÍNEZ, G. and SCHWARTZ, A. 2012. "Elevating 'Low' Language for High Stakes: A Case for Critical, Community-Based Learning in a Medical Spanish for Heritage Learners Program”, Heritage Language Journal, 9(2), 37-49.

MCGINNIS, E. I. and PALOS, A. L. 2011. Precious Knowledge [Motion picture]. United States: Dos Vatos Films.

MCINTOSH, P. 2000. "Interactive Phases of Personal and Curricular Revision with Regard to Race”, in Shin, G. and Gorski, P. (eds.), Multicultural Resource Series: Professional Development for Educators. Washington DC: National Education Association.

MENARD-WARWICK, J. 2009. Gendered Identities and Immigrant Language Learning. Buffalo, NY: Multilingual Matters.

MORAN, P. R. 2001. Teaching Culture: Perspectives in Practice. Boston: Heinle \& Heinle, Thomson Learning.

MORRIS, R. C. and MIMS, N. G. 2012. "Making Classrooms Culturally Sensitive", Education \& Culture, 16(1), 29-32.

NODDINGS, N. 1999. “Two Concepts of Caring”, Philosophy of Education. Retrieved from http:// www.ed.uiuc.edu/EPS/PES- yearbook/1999/noddings.asp.

$\mathrm{OH}$, J. S. and AU, T. K. 2005. "Learning Spanish as a Heritage Language: The Role of Sociocultural Background Variables", Language, Culture and Curriculum, 18(3), 229-241.

PAK. C. 2016. "Linking Service-learning with Sense of Belonging: A Culturally Relevant Pedagogy for Heritage Students of Spanish", Journal of Hispanic Higher Education, 1, 1-20.

PARRA, M. L. 2013. "Expanding Language and Cultural Competence in Advanced Heritage- and Foreign-Language Learners through Community Engagement and Work with the Arts", Heritage Language Journal, 10(2), 253-280.

PÉREZ PÉREZ, N. 2012. Análisis del contenido cultural en libros de texto de español como lengua extranjera destinados a estudiantes portugueses. $\mathrm{PhD}$ thesis. Oporto: Universidade do Porto.

PETERSON, E. and COLTRANE, B. 2003. "Culture in Second Language Teaching", CAL Digest, $3(9), 1-6$.

PETROV, L. A. 2013. "A Pilot Study of Service-learning in a Spanish Heritage Speaker Course: Community Engagement, Identity and Language in the Chicago Area”, Hispania, 96(2), 310-327.

PORCHER, L. 1986. La Civilisation. Paris: Clé International. 
POTOWSKI, K. and CARREIRA, M. 2004. "Teacher Development and National Standards for Spanish as a Heritage Language", Foreign Language Annals, 37(3), 427-437.

ROCA, A. 2007. "Intermediate-level Spanish as a Heritage Language: Issues in Developing Literacy”, AP Spanish Language. Special Focus: Teaching Writing, 142-154.

RODRÍGUEZ PINO, C. 1997. "Teaching Spanish to Native Speakers: A New Perspective in the 1990", The ERIC/CLL News Bulletin, 21(1), 4-5.

ROSS, A. and CHARITOS, S. 2012. "Hispanidades/Hispanicities: Modelling Micro-collaboration Across Institutions in Support of Student Learning and Research", Proceedings from The $52^{\text {nd }}$ Annual National Conference of the Japan Association for Language Education and Technology.

RUBIN, K. 2004. "Going Home to Study”, International Educator, 13(1), 26-33.

SAMANIEGO, F. and PINO, C. 2000. "Frequently Asked Questions about SNS Programs", in Webb, J. and Miller, B. (eds.), Teaching Heritage Language Learners: Voices from the Classroom. Yonkers, NY: ACTFL, 29-65.

SCHULZ, R. A. 2007. "The Challenge of Assessing Cultural Understanding in the Context of Foreign Language Instruction”, Foreign Language Annals, 40(1), 9-26.

SCHWARZER, D. and PETRÓN, M. 2005. "Heritage Language Instruction at the College Level: Reality and Possibilities", Foreign Language Annals, 38(4), 568-578.

SMITH, B. 1997. "Virtual Realia", The Internet TESL Journal, 3(7), 1-5.

STERN, G. 2004. "Inspiring Tales; AIC Course in Spanish for Native Speakers Stresses Culture”, The Hispanic Outlook in Higher Education, 14(23), 1-2.

TIJUNELIS, V., SATTERFIELD, T., and BENKÍ, J. R. 2013. "Linking Service-learning Opportunities and Domestic Immersion Experiences in US Latino Communities: A Case Study of the En nuestra lengua Project”, Hispania, 96(2), 264-282.

VALDÉS, G. 2000. "Introduction", in Anderson, N. (ed.), AATSP Professional Development Series Handbook for Teachers K-16. Vol. 1: Spanish for Native Speakers. New York: Harcourt College, 1-20.

VILLA, D. J. 1996. “Choosing a 'Standard' Variety of Spanish for the Instruction of Native Spanish Speakers in the US”, Foreign Language Annals, 29(2), 191-200.

WEBB, J. and MILLER, B. 2000. Teaching Heritage Language Learners: Voices from the Classroom. Yonkers, NY: ACTFL.

ZIMMERMAN, N. S. 2009. "Creating Google Maps to Encourage Heritage Speakers to Consider their Cultural Heritage", in Arries, J. (ed.), Language, Culture and Agency. Symposium Conducted at the 3oth Annual Conference of Mid-Atlantic Council of Latin American Studies. Williamsburg, VA: The College of William and Mary.

ZIMMERMAN, N. S. 2011. Who Is the Self That Teaches? A Perspective of Faculty as They Learn to Teach Spanish as a Heritage Language. PhD thesis. The Pennsylvania State University.

\section{ABOUT THE AUTHOR}

Clara Burgo is an Assistant Professor of Spanish at Loyola University Chicago, USA. 